Article

\title{
Luteinizing Hormone Effect on Luteal Cells Is Dependent on the Corpus Luteum Stage in Felids
}

\author{
Michał M. Hryciuk*, Katarina Jewgenow and Beate C. Braun
}

Citation: Hryciuk, M.M.; Jewgenow, K.; Braun, B.C. Luteinizing Hormone Effect on Luteal Cells Is Dependent on the Corpus Luteum Stage in Felids. Animals 2021, 11, 179.

https: / / doi.org/

10.3390/ani11010179

Received: 7 December 2020

Accepted: 8 January 2021

Published: 14 January 2021

Publisher's Note: MDPI stays neutral with regard to jurisdictional clai$\mathrm{ms}$ in published maps and institutional affiliations.

Copyright: (C) 2021 by the authors. Licensee MDPI, Basel, Switzerland. This article is an open access article distributed under the terms and conditions of the Creative Commons Attribution (CC BY) license (https:// creativecommons.org/licenses/by/ $4.0 /)$.
Leibniz Institute for Zoo and Wildlife Research, Department of Reproduction Biology, 10315 Berlin, Germany; jewgenow@izw-berlin.de (K.J.); braun@izw-berlin.de (B.C.B.)

* Correspondence: hryciuk@izw-berlin.de

Simple Summary: The corpus luteum is a transient endocrine gland on the mammalian ovary, and its main function is to produce progesterone. Knowledge about the corpus luteum in felids is very limited and luteolytic and luteotrophic factors which regulate its maintenance and regression are not extensively studied. Information about corpus luteum function is needed to understand breeding strategies and to successfully implement assisted reproductive techniques for felids, of which most of the species are threatened. The aim of this study was to reveal the effect of luteinizing hormone on cultured luteal cells from corpora lutea obtained from selected felids and to investigate the protein expression of steroidogenic enzyme $3 \beta$-hydroxysteroid dehydrogenase by immunohistology.

Abstract: The objective of this study was to investigate the effect of luteinizing hormone (LH) on steroidogenic luteal cells obtained from corpora lutea (CL) of the domestic cat and selected wild felids. Luteal cells were isolated enzymatically from CL at different developmental stages and cultured for two days in the presence and absence of $100 \mathrm{ng} / \mathrm{mL} \mathrm{LH}$, respectively. Functionality was assessed by progesterone (P4) accumulation in cell culture media determined by ELISA. In addition, steroidogenic function was confirmed using immunohistochemistry for $3 \beta$-hydroxysteroid dehydrogenase (HSD3B). The enzymatic method allowed for the isolation of mostly small luteal cells in all investigated felids. Treatment with LH resulted in an increase in P4 secretion of cultured luteal cells obtained from CL in the formation stage (African lion) and development/maintenance stage (domestic cat $(p<0.05)$, Javan leopard), whereas luteal cells from more advanced stages of luteal development (regression) responded moderately or not at all to LH stimulation (domestic cat, Asiatic golden cat, Asiatic lion). The protein signal for HSD3B on CL was visible until development/maintenance. In conclusion, this study shows that LH promotes $\mathrm{P} 4$ production in luteal cells only until the onset of regression, when morphological signs are visible on the CL of felids and HSD3B is no longer detectable.

Keywords: felids; luteal cells; steroidogenic activity; luteinizing hormone; domestic cat

\section{Introduction}

There are 38 wild felids listed on the IUCN Red List, and 25 of them are classified as near threatened, vulnerable or endangered (https:/ / www.iucnredlist.org). The main causes of felid population decline are due to habitat loss and fragmentation, humanwildlife conflicts, the illegal pet trade and traditional medicine [1]. To protect species from extinction, ex situ and in situ conservation programs have been established, but success also depends on knowledge on the reproduction cycles of felids. Among felids, there are species whose reproductive biology have never been described [2]. For only 24 species, some hormonal reproduction patterns are known currently [3]. Therefore, there is a critical need for more information about reproductive biology of felids to improve natural breeding or for the application in assisted reproductive techniques (ART) [4,5].

It is known that in most felids, ovulation is induced by copulation or some other form of physical or social interaction $[4,6]$, but some of these species also ovulate spontaneously, 
in particular when a mating partner is not available [4]. Ovulation is followed by the formation of corpus luteum (CL), which is a temporary gland on the ovaries. Its main function is the production of progesterone (P4) and maintaining pregnancy. In most studied species, the CL is composed of steroidogenic small (SLC) and large (LLC) luteal cells and nonsteroidogenic cells such as fibroblasts, endothelial cells, pericytes and cells originating from the bloodstream [7]. During its lifespan, four main stages can be distinguished-formation $(\mathrm{f})$, development/maintenance $(\mathrm{dm})$, early regression (er) and late regression (lr) [8].

Knowledge on CL in felids is limited mainly to domestic cats and lynxes. The functional lifespan of $C L$ in the domestic cat based on serum progesterone level should last around 40 days in case of non-pregnant cycle (pseudopregnancy) and around 65 days during pregnancy $[9,10]$. In non-domestic felids, the pregnancy length depends on the species and may last from 56 to 127 days [2]. The non-pregnant luteal cycle usually takes around half of the gestation period [2]. The luteal cycle usually ends with a full structural regression to corpora albicans. In the domestic cat, regressing CL or corpora albicans remain visible on the ovary for up to eight months [11]. Contrary, the CL of lynxes are characterized by a unique lifecycle. Formed after ovulation, CL do not regress after pregnancy (or pseudopregnancy) and lactation but transform into persistent $\mathrm{CL}$, which remains hormonally active for a period of at least two years [12].

Luteinizing hormone (LH) is a luteotrophic hormone whose action is crucial for the formation of CL [13]. This hormone is responsible for initiating differentiation of granulosa and theca cells to large luteal cells (LLC) and small luteal cells (SLC), respectively $[14,15]$. In the domestic cat, during estrus, LH quickly increases for a short period; then, its concentration decreases and oscillates to around $5 \mathrm{ng} / \mathrm{mL}[16,17]$. Furthermore, during estrus, two major peaks are detectable [18].

The influence of LH on CL of felids is not extensively studied. Functional testing on CL survival in any felid is limited due to its invasive character, regulations on animal experimentation and side effects on animals [19]. In addition, many felids are threatened which excludes any experimental access to the animal. Therefore, the only rational solution for functional testing is in vitro studies on cultured luteal cells.

The aim of this study was to investigate an effect of LH $(100 \mathrm{ng} / \mathrm{mL})$ on luteal cells from the domestic cat and selected wild felids during two days of culture. In addition, the expression of $3 \beta$-hydroxysteroid dehydrogenase (HSD3B) was confirmed by immunohistology on CL tissues. The experiments we performed on CL from the formation, development/maintenance and early and late regression stages. The enzymatic isolation method and culture conditions previously described for domestic cats were applied [20]. The presented studies were conducted to contribute to knowledge about CL of felids.

\section{Materials and Methods}

This study was approved by the Internal Committee for Ethics and Animal Welfare of the Leibniz Institute for Zoo and Wildlife Research (IZW) (2017-02-02). Ovarian samples from domestic cats were obtained from routinely ovariectomized queens in an animal shelter in Berlin. The reason for the ovariectomies was not related to the purpose of this experiment. Analyzed samples from wild felids were obtained from captive animals during necropsy at the wildlife pathology lab of the IZW or were isolated after euthanasia for management or health reasons in European zoos and were transported to the IZW under the Felid Gametes Rescue Project [21]. Detailed information about individuals from wild felids is listed in Table 1.

All chemicals used in the experiments were purchased from Merck KGaA (Darmstadt, Germany) unless otherwise stated. 
Table 1. Detailed information about samples from felid species and replicate numbers.

\begin{tabular}{|c|c|c|c|c|c|c|}
\hline \multirow[t]{2}{*}{ Species } & \multirow{2}{*}{$\begin{array}{l}\text { Age of } \\
\text { Animal } \\
\text { (Years) }\end{array}$} & \multirow[t]{2}{*}{$\begin{array}{l}\text { Sample } \\
\text { Origin }\end{array}$} & \multirow{2}{*}{$\begin{array}{c}\text { Number of } \\
\text { CL Per } \\
\text { Animal }\end{array}$} & \multirow{2}{*}{$\begin{array}{c}\text { Number of Biological } \\
\text { Replicates for Cell } \\
\text { Cultures }\end{array}$} & \multicolumn{2}{|c|}{$\begin{array}{c}\text { Total Number of Technical } \\
\text { Replicates }\end{array}$} \\
\hline & & & & & Day 1 & Day 2 \\
\hline $\begin{array}{c}\text { African lion } \\
\text { (Panthera leo leo) }\end{array}$ & 7 & $\begin{array}{l}\text { Givskud Zoo } \\
\text { in Denmark }\end{array}$ & 3 & 1 & $\begin{array}{l}\text { Control: } 6 \\
\text { LH: } 14\end{array}$ & $\begin{array}{l}\text { Control: } 3 \\
\text { LH: } 11\end{array}$ \\
\hline $\begin{array}{l}\text { Domestic cat } \\
\text { (Felis catus) }\end{array}$ & * & $\begin{array}{l}\text { Tierheim } \\
\text { Berlin }\end{array}$ & * & $\begin{array}{l}5 * \\
3 *\end{array}$ & $\begin{array}{l}\text { Control: } 22 \\
\text { LH: } 22 \\
\text { Control: } 18 \\
\text { LH: } 18\end{array}$ & $\begin{array}{l}\text { Control: } 20 \\
\text { LH: } 20 \\
\text { Control: } 9 \\
\text { LH: } 9\end{array}$ \\
\hline $\begin{array}{c}\text { Javan leopard } \\
\text { (Panthera pardus } \\
\text { melas })\end{array}$ & 13 & $\begin{array}{l}\text { Tierpark } \\
\text { Berlin }\end{array}$ & 3 & 1 & $\begin{array}{l}\text { Control: } 6 \\
\text { LH: } 14\end{array}$ & $\begin{array}{l}\text { Control: } 3 \\
\text { LH: } 11\end{array}$ \\
\hline $\begin{array}{l}\text { Sumatran tiger } \\
\text { (Panthera tigris } \\
\text { sondaica) }\end{array}$ & 18 & Zoo Frankfurt & 2 & $* *$ & $* *$ & $* *$ \\
\hline $\begin{array}{l}\text { Asiatic golden cat } \\
\text { (Catopuma } \\
\text { temminckii) }\end{array}$ & 11 & $\begin{array}{l}\text { Allwetterzoo } \\
\text { Münster }\end{array}$ & 1 & 1 & $\begin{array}{l}\text { Control: } 6 \\
\text { LH: } 9\end{array}$ & $\begin{array}{l}\text { Control: } 3 \\
\text { LH: } 6\end{array}$ \\
\hline $\begin{array}{l}\text { Asiatic lion } \\
\text { (Panthera leo } \\
\text { persica) }\end{array}$ & 12 & $\begin{array}{l}\text { Aalborg Zoo } \\
\text { in Denmark }\end{array}$ & undefined & 1 & $\begin{array}{l}\text { Control: } 2 \\
\text { LH: } 12\end{array}$ & $\begin{array}{l}\text { Control: } 0^{* * *} \\
\text { LH: } 10\end{array}$ \\
\hline $\begin{array}{c}\text { Margay cat } \\
\text { (Leopardus wiedii) }\end{array}$ & 10 & $\begin{array}{l}\text { Tierpark } \\
\text { Berlin }\end{array}$ & 1 & $* *$ & $* *$ & $* *$ \\
\hline
\end{tabular}

* Age and number of CL per animal are not shown, as experiments were performed on five different animals in which CLs were classified in the development/maintenance stage and three animals in which CLs were classified in the early regression stage. ${ }^{* *}$ Luteal cell cultures were not performed due to the limited amount of luteal tissue. ${ }^{* * *}$ Was not included due to the limited number of isolated cells and design of the study.

\subsection{Samples Transport and Isolation of $C L$}

The samples from wild felids were transported to the lab in plastic tubes filled with saline solution within $24 \mathrm{~h}$ after extirpation of gonads. During transportation, the tubes were cooled by ice packs. The samples from domestic cats were delivered to the laboratory within around five hours after surgery. Immediately upon receiving, ovaries of felids were washed in Dulbecco's Phosphate Buffered Saline (DPBS) and CLs were dissected, washed in DPBS, trimmed to remove connective tissue and washed once again. From each individual, a small piece of one CL was cut out and incubated in Bouin solution for standard histology by hematoxylin and eosin staining and for immunohistochemistry (see below).

\subsection{Isolation of Luteal Cells}

Enzymatic isolation of small luteal cells from the domestic cat has been described previously [20] and was used without modifications in this study. Briefly, CLs were chopped on a petri dish with culture medium (HAM's F12 and MEM Eagle medium 1:1 (v:v) supplemented with $5 \%$ of fetal bovine serum (FBS) and $0.055 \mathrm{mg} / \mathrm{mL}$ gentamicin). The luteal tissue pieces were then transferred onto a $40 \mu \mathrm{m}$ cell strainer, immersed in culture medium supplemented with collagenase $0.1 \%$ (type I and II, SERVA Electrophoresis $\mathrm{GmbH}$ ) and $0.005 \%$ DNase. The tissue pieces were digested at $39^{\circ} \mathrm{C}$ for $55 \mathrm{~min}$ and were thereafter gently smashed through the cell strainer. This cell suspension was washed by centrifugation $(7 \mathrm{~min}, 1000 \times \mathrm{g}$ ) and the cell pellet was re-suspended in a $2 \mathrm{~mL}$ culture medium. The cell suspension was laid on a $40 \%$ percoll layer in a test tube and centrifuged $(7 \mathrm{~min}, 1000 \times \mathrm{g})$. Afterwards, luteal cells were collected from the interphase and were washed again by centrifugation $(4 \mathrm{~min}, 500 \times g)$. Finally, the cells were re-suspended in fresh culture medium and the cell count was determined in a hemocytometer. Viability staining of the cells was not performed due to low number of obtained cells and its unique 
character. All isolated cells were used to increase number of technical repeats within treatment groups.

\subsection{Cell Culture Conditions and Cell Diameter Evaluation}

The obtained luteal cell suspension was divided into a control group (culture medium) and an LH treatment group. The cell concentration was brought to 200,000 cells per mL by diluting the cells with the respective culture medium. The final concentration of $\mathrm{LH}$ (from human pituitary) in the treatment group was $100 \mathrm{ng} / \mathrm{mL}$. Cells (30,000 cells per $150 \mu \mathrm{L}$ ) were seeded into 96-well Tissue Culture Plates (Sarstedt AG \& Co KG, Nümbrecht, Germany) previously coated with $15 \mu \mathrm{L}$ of $0.02 \%$ Collagen R (Serva Electrophoresis $\mathrm{GmbH}$, Heidelberg, Germany) in DPBS to improve cells attachment. The total number of technical and biological replicates for each species is shown in Table 1. Cells were cultured for two days at $39{ }^{\circ} \mathrm{C}, 5 \% \mathrm{CO}_{2}$. The cell culture medium was changed each day by replacing $130 \mu \mathrm{L}$ medium with a freshly prepared one. The collected medium was stored at $-20^{\circ} \mathrm{C}$ until hormone extraction. Each day, the cells were microscopically analyzed under the Axiovert $200 \mathrm{M}$ microscope (Carl Zeiss, Oberkochen, Germany), which was equipped with a ProgRes ${ }^{\circledR}$ C3 camera (JENOPTIK Optical Systems GmbH, Berlin, Germany) that was connected to a computer with the program CapturePro 2.20.01. Photos were taken and archived to measure the cell diameters with the program cell`D (Olympus Soft Imaging Solutions $\mathrm{GmbH}$, Münster, Germany).

\section{4. $3 \beta$-hydroxysteroid dehydrogenase Assay}

Identification of steroidogenic luteal cells was performed by determination of enzyme activity of $3 \beta$-hydroxysteroid dehydrogenase (HSD3B) in freshly isolated and cultured cells [20]. The assay was performed on day two of culture. Before staining, the cells were fixed in $1 \%$ formaldehyde solution at $39^{\circ} \mathrm{C}$ for $15 \mathrm{~min}$, followed by washing twice in DPBS and adding the staining/control solution $(1.5 \mathrm{mM}$ nicotinamide adenine dinucleotide, $0.25 \mathrm{mM}$ nitrotetrazolium blue chloride, $0.2 \mathrm{mM}$ pregnenolone, $2 \mathrm{mM}$ ethylenediaminetetraacetic acid, $0.1 \%$ BSA). Cells were left in a staining/control solution for overnight incubation at $39^{\circ} \mathrm{C}$. On the following day, cells were washed twice in DPBS and the staining intensity within cells was documented by microphotography. For control, activity of $3 \beta$-hydroxysteroid dehydrogenase was blocked by $2 \mathrm{mM}$ trilostane as described before [20].

\subsection{P4 Extraction and ELISA Measurements}

Hormone extraction and measurement was done as described before [20]. Hormones were extracted from $100 \mu \mathrm{L}$ culture media supernatant. Extracts were dissolved in $200 \mu \mathrm{l}$ $40 \%$ methanol and were stored at $-20^{\circ} \mathrm{C}$ until $\mathrm{P} 4$ measurements. P4 analyses were carried out with an in-house microtiter plate enzyme immunoassay as described earlier [22] using a commercial P4 antibody (Sigma P1922, raised in rats to P4) and 4-pregnen-3,20dione-3-CMO-peroxidase label. The cross-reactivity to other steroids were as follows: 4-pregnen-3,20-dione (P4), 100\%; 5a-pregnan-3,20-dione, 31\%; 5a-pregnan-3b-ol-20-one, $18 \%$; 5-pregnen-3b-ol-20-one, $12 \%$; 4-pregnen-3aol-20-one, $4.2 \%$; $<0.1 \%$ for $5 \mathrm{~b}$-pregnan3a,20adiol, 4-pregnen-20a-ol-3-one, 5b-pregnan-3a-ol-20-one, 5a-pregnan-20a-ol-3-one, 5apregnan-3a,20 a-diol, 5a-pregnan-3b,20a-diol, testosterone, estradiol and cortisol. Samples were partly diluted with $40 \%$ methanol and were measured in duplicates. Parallelism of diluted samples and the linearity of the method were confirmed. Inter- and intra-assay coefficient results for the two biological samples were $11.0 \%$ and $4.8 \%$ and $7.6 \%$ and $2.8 \%$, respectively. Extraction recovery for the control sample was $88.9-99.7 \%$. Results for samples after two days in culture describe the values with the subtracted amount of remaining progesterone produced during the first day of culture period. This correction was done on a per-well basis. 


\subsection{Immunohistochemistry and Evaluation of Immunoreactivity}

Immunohistochemistry (IHC) was performed as described previously in Braun et al. [23]. Briefly, CL tissue pieces were fixed in Bouin's solution, embedded in paraffin, sliced to 3 $\mu \mathrm{m}$ thicknesses and mounted on microscope slides (Superfrost Plus, Thermo Scientific). The slides were then deparaffinized in Roti Histol (Carl Roth $\mathrm{GmbH}$ ) and rehydrated in decreasing concentrations of ethanol. Afterwards, slides were incubated overnight with diluted primary antibody (Table 2). Control staining was incubated with blocking solution; furthermore, we tested and confirmed that the primary antibodies did not cause an unspecific staining pattern on ovaries (not shown). The next day, the slices were incubated with the appropriate second antibody solution (Table 2) before binding of antibodies was visualized by incubation for $5 \mathrm{~min}$ for all samples with diaminobenzidine (DAB) substrate chromogen solution (Dako Deutschland GmbH, Hamburg, Germany). Sections were counterstained with hematoxylin dehydrated in increasing concentrations of ethanol, and covered with mounting medium and coverslips. Stained CL were observed under inverted microscope (IX81, Olympus Deutschland GmbH, Hamburg, Germany) with a $40 \times$ objective. Pictures of the CL sections from different stages and species were taken with a DP72 camera (Olympus) and CellSens imaging software (Olympus) with the same settings to provide identical conditions. HSD3B was chosen as a representative steroidogenic enzyme, since we could show in a former study that the HSD3B protein signals (detected by Western Blot with the same antibody) reflected the intraluteal P4 values in domestic cat CL [24]. Results and conclusions for immunohistochemistry are based on staining for three individuals at formation, development/maintenance and early and late regression stages for domestic cats and single individual wild felids.

Table 2. Description of primary and secondary antibodies used for immunohistochemistry.

\begin{tabular}{ccccc}
\hline Antibody & Host & Type & Dilution & Source \\
\hline anti-HSD3B & & & & Santa Cruz Biotechnology Inc., \\
& mouse & primary & $1: 500$ & Heidelberg, Germany; \\
sc-100466 & BIOZOL Diagnostica Vertrieb \\
ImmPRESS ${ }^{\text {TM }}$ VR & & & & GmbH, Eching, Germany; \\
REAGENT Anti-Mouse & goat & secondary & ready to use & PEROXIDASECat. No. \\
IgG Kit & & & & MP-6402 \\
\hline
\end{tabular}

\subsection{Assessment of CL Stages in Wild Felids}

The assessment based on previously described characteristic for the domestic cat [8] was combined with morphological features of the gland, such as the presence of an ovulation scar, CL size and its location on the ovary. Microphotographs of CLs at different developmental stages from domestic cats were compiled together with microphotographs of CLs from different wild felids for comparison (Figure 1). The CLs of the African lion were not fully formed and had signs of recent ovulation. The gland was composed of steroidogenic luteal cells of different sizes and shapes from elongated to round or polyhedral (Figure 1E). The cells had a moderate number of small vacuoles localized mainly in the cells' periphery and the CL showed signs of neovascularization. All of those features were similar to CLs from domestic cats at the formation stage (Figure 1A). The sample from the Javan leopard had similarities to CL at development/maintenance of the domestic cat (Figure 1B) because most of the cells were large and had a polyhedral shape, and vacuoles were distributed through the cytoplasm, but some elongated cells were also found (Figure 1F). Asiatic golden cat CL was characterized by oval or round steroidogenic luteal cells with two types of vacuoles; small ones were distributed in a cell cytoplasm and large ones were found only in some of the luteal cells (Figure 1H). The presence of the second vacuole type allowed us to classify the CL to the early regression stage. Classification of CL stages for the Asiatic lion, Margay cat and Sumatran tiger could not be 
easily assessed. The Sumatran tiger CL was very small in size (a diameter of around $2 \mathrm{~mm}$ ), which seemed to be comparable with the size of CLs in a late regression stage of domestic cats. Interestingly, the gland was composed of a polyhedral LLC compactly filled with small, moderate or large vacuoles (Figure 1G); therefore, the transition stage between the development/maintenance and early regression stage was suggested. The CL of the Asiatic lion was very small in size. The LLC/SLC were found only on a small area of the gland and they were surrounded by cells whose cytoplasm to nucleus ratio was lower in comparison to the LLC/SLC (Figure 1I). The gland did not show any signs of neovascularization, and it appeared that the regression process was proceeding towards the LLC/SLC area. Despite the lack of many large vacuoles, which are typical for advanced regression in domestic cats (Figure 1D), the CL was classified as late regression. The Margay cat CL was very smallsized and was mainly composed of cells which looked like small luteal cells with a similar nucleus to cytoplasm ration (Figure 1J) and nonsteroidegenic cells. The steroidogenic cells looked like they might have already undergone processes of conversion. Therefore, despite the absence of large vacuoles, the CL were classified to the late regression stage.

\subsection{Statistical Analysis}

Progesterone analysis for the domestic cat describes results from five different individuals in which CL has been classified as being in the development/maintenance stage $(n=5)$ and three individuals in which CL has been classified as being in the early regression stage $(n=3)$ (Table 1). In the statistical analysis, all technical repeats from all biological replicates had been used. A Mann-Whitney Test was used to assess statistical differences between the control and LH test group at the same time point of the cultured cells. The analysis was performed in R (R: A language and environment for statistical computing (2018); $\mathrm{R}$ Foundation for Statistical Computing, Vienna, Austria; v. 3.5.0). $p$-values lower than 0.05 were considered as significant. Statistical analysis was not performed for data of wild felids because results represent single individuals $(n=1)$.

The P4 concentration in a medium of cultured luteal cells was shown in a vertical box plot by plotting medians and the 10th, 25th, 75th and 90th percentiles (Sigma.Plot 10.0 Systat software GmbH, Erkrath, Germany). 


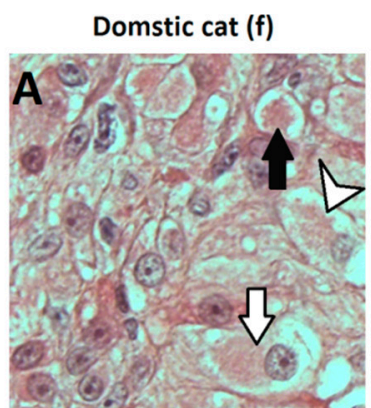

African lion (f)

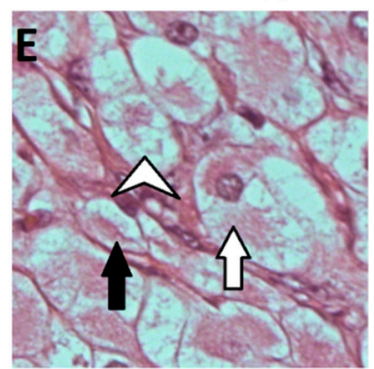

Asiatic lion (Ir)

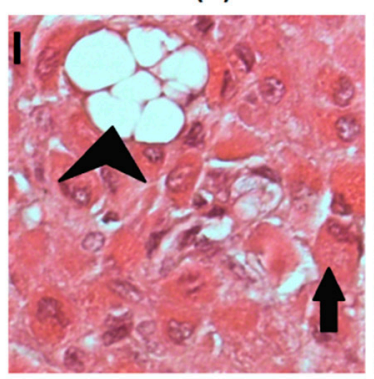

Domestic cat $(\mathrm{dm})$

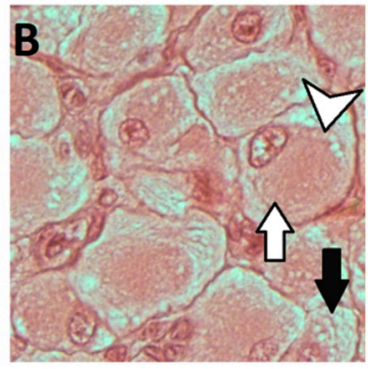

Javan leopard (dm)

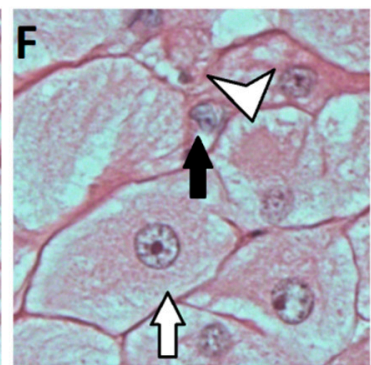

Margay cat (Ir)

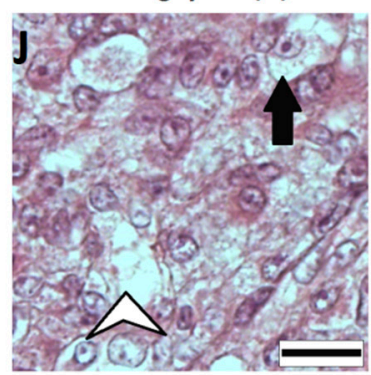

Domestic cat (er)

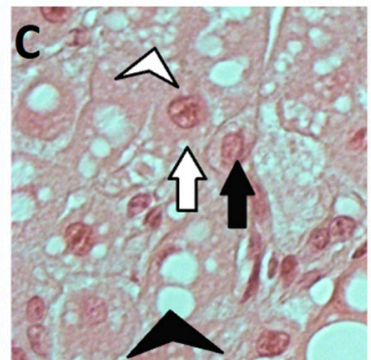

Sumatran tiger (dm/er)

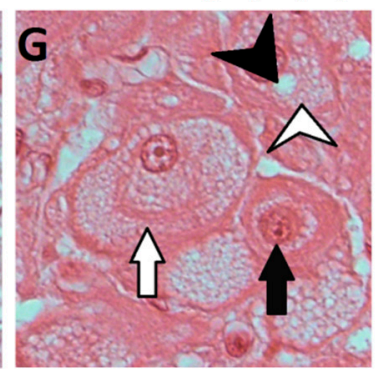

Domestic cat (Ir)

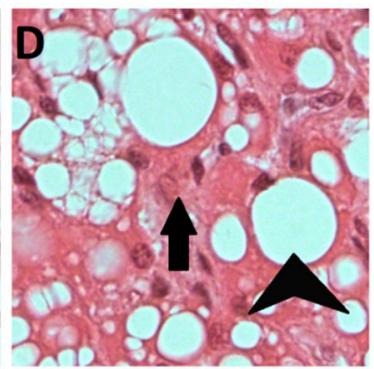

Asiatic golden cat (er)

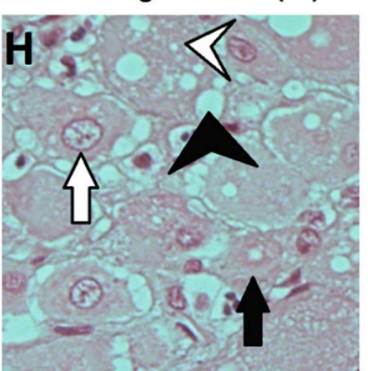

Figure 1. Hematoxylin and eosin staining of corpus luteum (CL) from domestic cat (A-D) and wild felid (E-J) species at different developmental stages. (A) CL from the domestic cat in the formation stage-luteal cells have different sizes and shapes, from elongated to round or polyhedral. Small vacuoles are present in the cell cytoplasm; (B) CL from the domestic cat in the development/maintenance stage-luteal cells are fully grown, have a polyhedral shape and contain high degree of small vacuoles; (C) CL from the domestic cat in the early regression stage-luteal cells contain small and large vacuoles and their shape may be partly deformed; (D) CL from the domestic cat in the late regression stage-luteal cells are deformed because of the presence of high numbers of large vacuoles; (E) CL from the African lion in the formation stage-luteal cells have different sizes and small vacuoles; (F) CL from the Javan leopard in the development/maintenance stage-luteal cells are large or medium-sized and have polyhedral shape, indicating a development rather than a maintenance stage; (G) CL from the Sumatran tiger in the development/maintenance-early regression stage-luteal cells have a degree of small vacuoles with single large vacuoles in some of the cells; $(\mathbf{H})$ CL from the Asiatic golden cat in the early regression stage-luteal cells have a round or polyhedral shape with large and small vacuoles; (I) CL from the Asiatic lion in the late regression stage - single small (SLC) or large (LLC) luteal cells with a round shape are visible, but most of the cells are small and deformed. Rare large vacuoles are visible; (J) CL from Margay cat in the late regression stage-single SLC or LLC with an oval shape are visible while other cells are densely packed. A black arrow indicates SLC; a white arrow indicates LLC; a white arrow head indicates small vacuoles; a black arrow head indicates large vacuoles. $\mathrm{f}-\mathrm{formation}$, $\mathrm{dm}$-development/maintenance, er-early regression, $\mathrm{lr}$-late regression. Scale bar is equal to $20 \mu \mathrm{m}$.

\section{Results}

\subsection{Characteristics of Isolated and Cultured Cells}

Size classification of SLC and LLC followed the previously established description for the domestic cat $[20,25]$. The SLC were characterized by diameters smaller or equal to $20 \mu \mathrm{m}$ and LLC by diameter above $20 \mu \mathrm{m}$. The average diameter of all isolated cells for each species and percentage of SLC in cell suspension of all isolated cells are presented 
in Table 3. In all studied species, the average diameter of isolated cells indicated that mainly SLC were isolated; however, histological microphotographs (Figure 1) indicated the presence of a higher numbers of LLC in comparison with SLC in most of studied species. Only the suspension obtained from CL of the Javan leopard contained two very distinctive small and large cells types (Figure 2E), and the relation between SLC and LLC could not be determined here, because the SLC were in clumps, making counting unreliable. Isolated SLC from all analyzed felids had a round shape, and in some of them, small lipid droplets were visible, especially those in which the diameter was greater than $15 \mu \mathrm{m}$. The behavior of SLC in the culture was similar to what was described before for the domestic cat, but the LLC of wild felids, in contrast to our previous experiments with the LLC of domestic cats isolated mechanically [20], flattened to the bottom of the culture well.
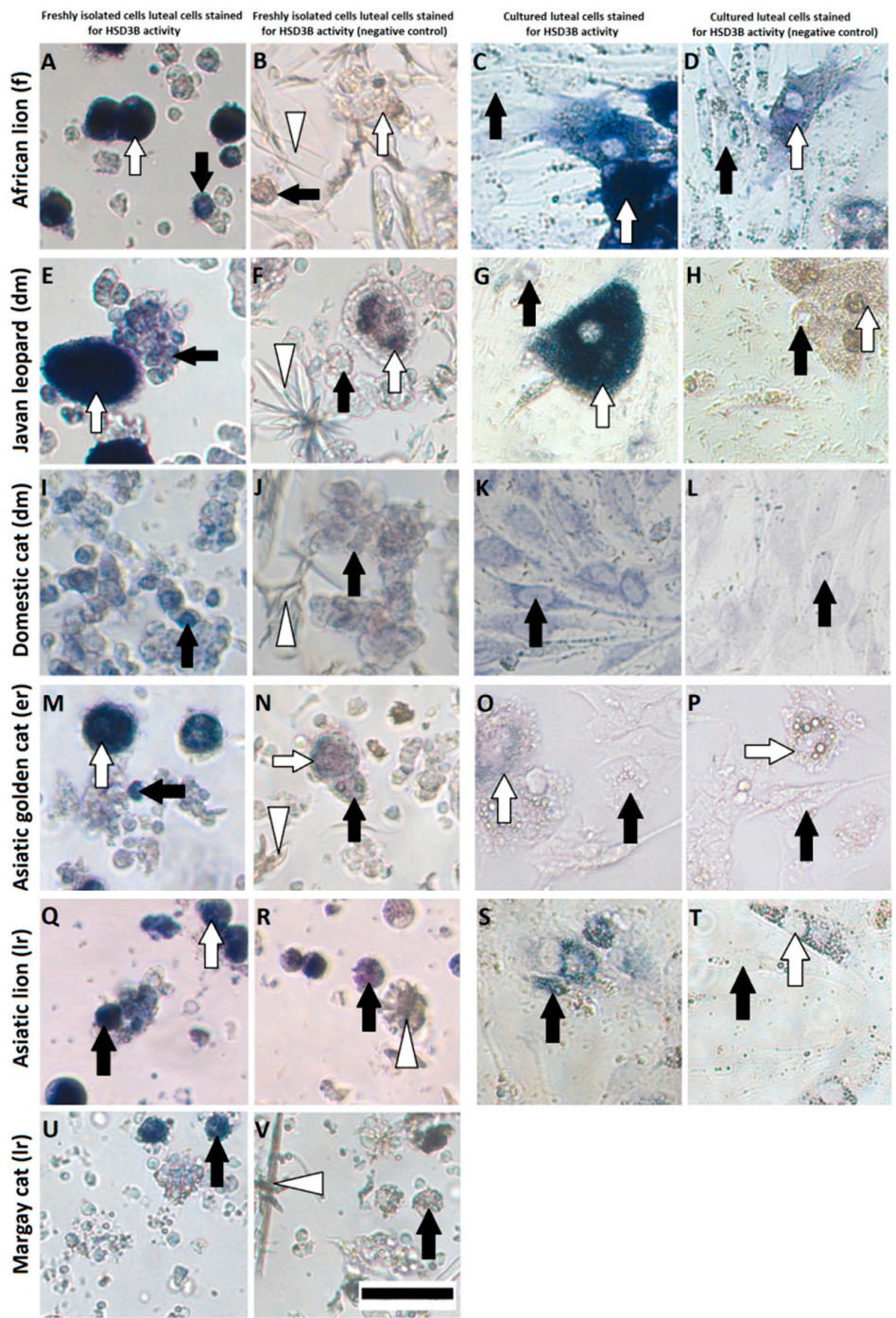

Figure 2. Freshly isolated cells $(\mathbf{A}, \mathbf{B}, \mathbf{E}, \mathbf{F}, \mathbf{I}, \mathbf{J}, \mathbf{M}, \mathbf{N}, \mathbf{Q}, \mathbf{R}, \mathbf{U}, \mathbf{V})$ and luteal cells cultured for two days $(\mathbf{C}, \mathbf{D}, \mathbf{G}, \mathbf{H}, \mathbf{K}, \mathbf{L}, \mathbf{O}, \mathbf{P}, \mathbf{S}, \mathbf{T})$ from the domestic cat (I-L) and wild felids (A-H,M-V) stained for activity of HSD3B. Luteal cells from the Margay cat were isolated but not cultured because of a limited number of obtained cells. Luteal cells with high steroidogenic capacity are stained with a dark blue color. Activity of HSD3B in control groups $(\mathbf{B}, \mathbf{F}, \mathbf{J}, \mathbf{N}, \mathbf{R}, \mathbf{V}, \mathbf{D}, \mathbf{H}, \mathbf{L}, \mathbf{P}, \mathbf{T})$ was blocked by trilostane (2 mM), and the light blue or purple color of these cells come from other NAD+-dependent metabolic reactions. A white arrow indicates LLC; a black arrow indicates SLC; a white triangle indicates a crystal of trilostane. $\mathrm{f}$-formation, dm-development/maintenance, er-early regression, $\mathrm{lr}$-late regression. Scale bar is equal to $50 \mu \mathrm{m}$. 
Table 3. Information about the population of isolated cells.

\begin{tabular}{|c|c|c|c|c|}
\hline Species & $\begin{array}{c}\text { Average Diameter } \\
\text { of Isolated Cells } \pm \\
\text { Standard Deviation } \\
(\mu \mathrm{m})\end{array}$ & $\begin{array}{c}\text { Number of } \\
\text { Counted Cells }\end{array}$ & $\begin{array}{l}\text { Percentage of SLC in } \\
\text { Isolated Population } \\
\text { of Cells (\%) }\end{array}$ & CL Stage Based on Histology \\
\hline $\begin{array}{c}\text { African lion } \\
\text { (Panthera leo leo) }\end{array}$ & $14.5 \pm 4.6$ & 172 & 83.7 & $\begin{array}{l}\text { formation (corpus } \\
\text { hemorrhagicum) [f] }\end{array}$ \\
\hline $\begin{array}{l}\text { Domestic cat } \\
\text { (Felis catus) }\end{array}$ & $11.5 \pm 2.3$ & 253 & 99.6 & development/maintenance $[\mathrm{dm}]$ \\
\hline $\begin{array}{c}\text { Javan leopard } \\
\text { (Panthera pardus melas) }\end{array}$ & $\begin{array}{l}11.5 \pm 2.3^{*} \\
37.5 \pm 5.6^{*}\end{array}$ & $\begin{array}{c}100 \\
11\end{array}$ & $* *$ & development/maintenance $[\mathrm{dm}]$ \\
\hline $\begin{array}{l}\text { Asiatic golden cat } \\
\text { (Catopuma temminckii) }\end{array}$ & $10.5 \pm 4.5$ & 136 & 94.1 & regression [er] \\
\hline $\begin{array}{c}\text { Asiatic lion } \\
\text { (Panthera leo persica) }\end{array}$ & $13.3 \pm 4.1$ & 115 & 93.3 & regression [lr] \\
\hline $\begin{array}{c}\text { Margay cat } \\
\text { (Leopardus wiedii) }\end{array}$ & $10.8 \pm 3.1^{* * *}$ & 52 & 100.0 & regression $[1 \mathrm{lr}]$ \\
\hline
\end{tabular}

* In steroidogenic cells from the Javan leopard, average diameter was calculated separately, because isolated cell suspension contained two distinctive cells types and SLC were in clumps, making counting unreliable. ${ }^{* *}$ Percentage of SLC in the isolated cell population from the Javan leopard was not calculated because SLC were in clumps. ${ }^{* * *}$ Steroidogenic cells from the Margay cat were measured after staining them for HSD3B activity.

\subsection{Identification of Steroidogenic Cells in Freshly Isolated and Cultured Cells}

The steroidogenic activity of cells was mirrored by the amount of accumulated formazan within the cells' cytoplasm (Figure 2). Isolated SLC (usually smaller than $15 \mu \mathrm{m}$ ) of the domestic cat, Javan leopard and Asiatic lion (Figure 2E,I,Q) had a low steroidogenic capacity, which was mirrored by blue or partially blue staining. The SLC in the African lion or Margay cat cultures were characterized by greater number of cells which did not show any steroidogenic activity in comparison to previously mentioned species (Figure $2 \mathrm{~A}, \mathrm{U}$ ). All large cells were stained dark blue independently of the stage and species, hinting to a high steroidogenenic capacity (Figure 2A,E,M,Q). During the culture period, LLC also express high steroidogenic capacity, while most of the SLC were characterized by a very low or a lack of HSD3B activity (Figure 2C,G,K,O,S). Only single SLC were able to maintain its steroidogenic capacity to a level comparable with that observed after isolation.

\subsection{P4 Secretion in Luteal Cell Cultures}

P4 secretion during the culture period varied greatly between species and developmental stages of CL (Figure 3). For all cell cultures, the highest amount of P4 was measured in medium collected after one day of cell culture. In media of day 2 , the P4 concentration decreased. Without LH supplementation, the lowest decrease in P4 concentration was observed in the Asiatic golden cat (CL early regression) (Figure 3D).

For the domestic cat, the concentration of P4 in medium without LH from luteal cells in the development/maintenance stage $(n=5)$ (Figure 3B) was almost five times higher in comparison to cells obtained from early regression $(n=3)$ (Figure 3E). Treatment with LH resulted in a higher average $\mathrm{P} 4$ concentration $(p<0.05)$ from the development/maintenance stage, at least during the first day of incubation (Figure 3B), compared to treatment without LH. The average increase in P4 production was $24 \%$.

Treatment with LH resulted in higher measured values (no statistics performed, $n=1$ ) for P4 medium concentrations in the African lion (CL formation, Figure 3A, day 1 and 2), Javan leopard (CL development/maintenance, Figure 3C, day 2) and Asiatic golden cat (CL early regression, Figure 3D, day 1). Almost no effect was measured in the CL regression stage of the Asiatic lion (Figure 3F). 
Progesterone concentration in cultured luteal cells from African lion $\mathrm{CL}$ formation stage
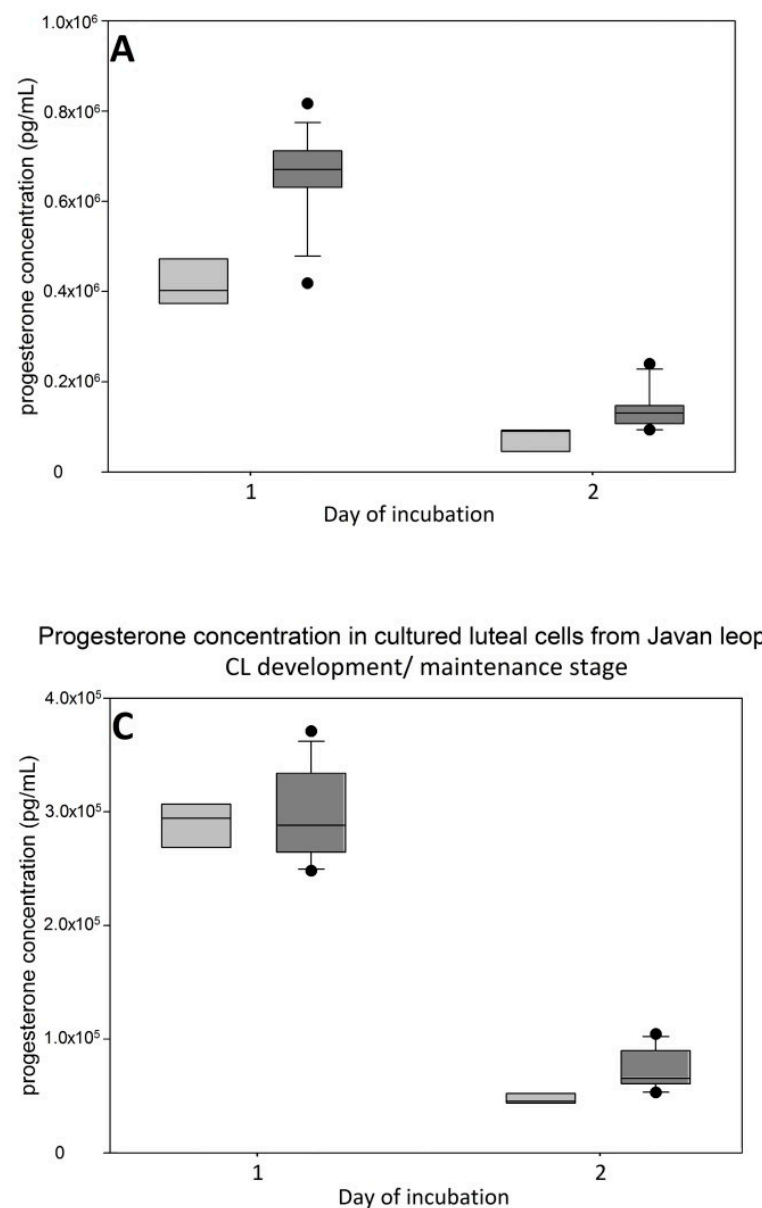

Progesterone concentration in cultured luteal cells from Domestic cat $\mathrm{CL}$ early regression stage

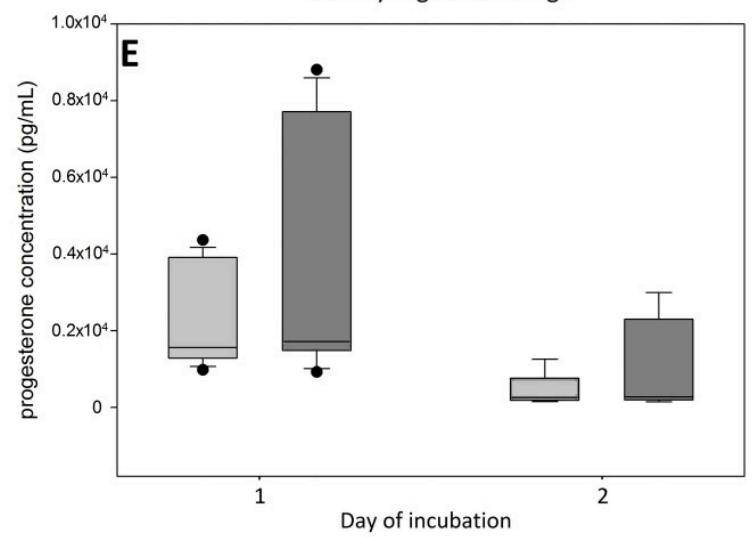

Progesterone concentration in cultured luteal cells from Domestic cat $\mathrm{CL}$ development/ maintenance stage

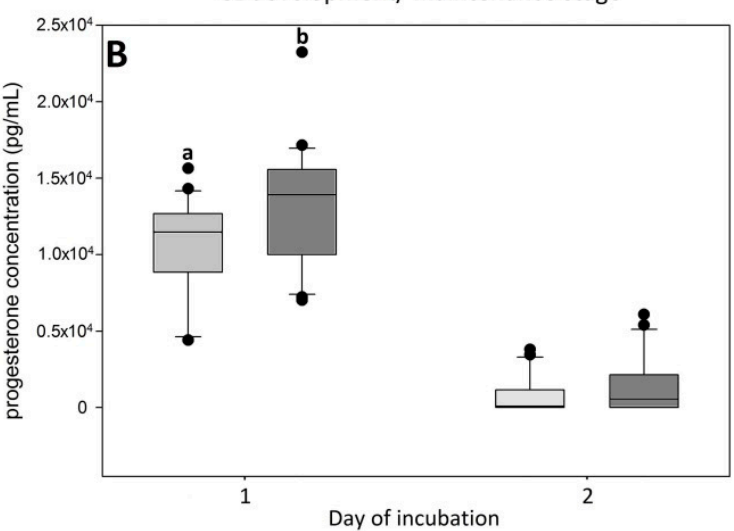

Progesterone concentration in cultured luteal cells from Asiatic golden cat

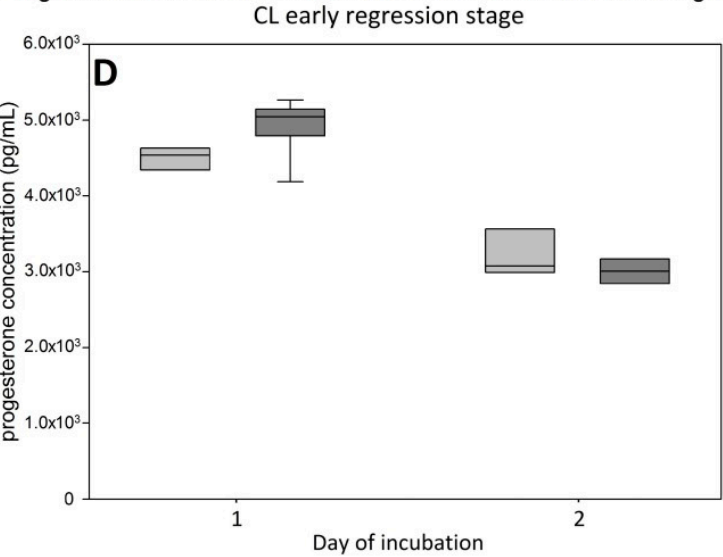

Progesterone concentration in cultured luteal cells from Asiatic lion $\mathrm{CL}$ late regression stage

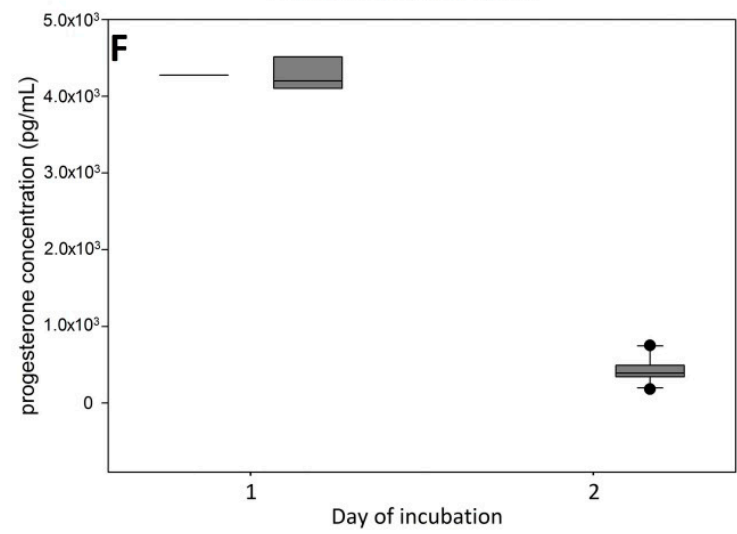

Figure 3. P4 concentration in medium of cultured luteal cells of the domestic cat ((B) development/maintenance $(n=5)$, (E) early regression $(n=3))$ and wild felid species at different CL stages ((A) African lion $(n=1)$, formation; (C) Javan leopard $(n=1)$, development/maintenance; (D) Asiatic golden cat $(n=1)$, early regression; (F) Asiatic lion $(n=1)$, late regression) showed as box plots of median (horizontal line), 25th and 75th percentiles (lower/upper end of box) and 10th and 90th percentiles (whiskers); black dots indicate outliers. Light grey-control group, grey-LH $100 \mathrm{ng} / \mathrm{mL}$ group. Statistical Mann-Whitney was applied only on samples from the domestic cat. Small letters indicate statistically significant different groups $(p<0.05)$ at the same day of incubation. In the cell culture of the Asiatic lion, progesterone concentration in the control group at day 2 was not measured because of limited number of cells. 


\subsection{Protein Expression of HSD3B by Immunohistology}

By immunohistology, the expression of HSD3B proteins was localized on the tissue sections of CL (Figures 4 and 5). HSD3B protein signals were found in the cytoplasm of large and small luteal cells. In the domestic cat, the protein signal for HSD3B was moderate at the formation stage (Figure $4 \mathrm{~A}$ ) and was strongest at the development/maintenance stage (Figure $4 \mathrm{C}$ ). Very weak or no signals were observed on the $C L$ when the first signs of structural regression appeared and regression progressed (Figure 4E,G). Signals for the HSD3B protein in CL from wild felids (Figure 5) fit the observations for CL from the domestic cat, where the signal was moderate or strong during the formation and development/maintenance stages and was not detectable or very low during regression stages. Exceptions were the CL from Sumatran tiger, which were classified to the maintenance/development-early regression stage but expressed a high HSD3B protein signal (Figure 5E).

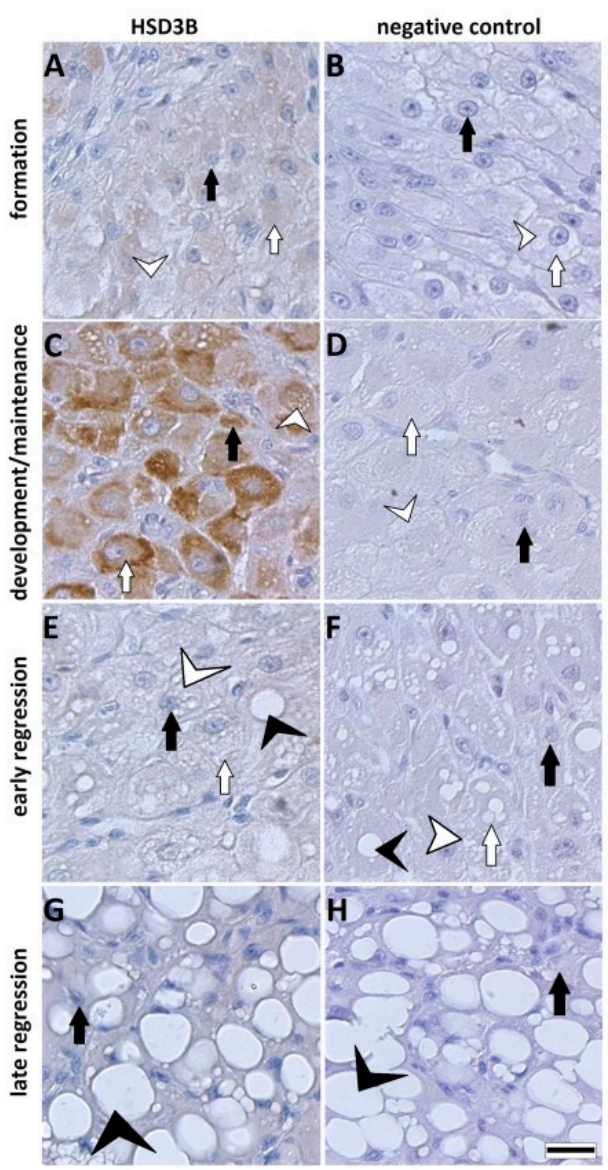

Figure 4. Immunohistochemical staining for $\operatorname{HSD} 3 B(\mathbf{A}, \mathbf{C}, \mathbf{E}, \mathbf{G})$ and negative control $(\mathbf{B}, \mathbf{D}, \mathbf{F}, \mathbf{H})$ in $C L$ from the domestic cat at different developmental stages. HSD3B protein signal was detected in a cytoplasm of SLC and LLC. Scale bar is equal to $20 \mu \mathrm{m}$. 


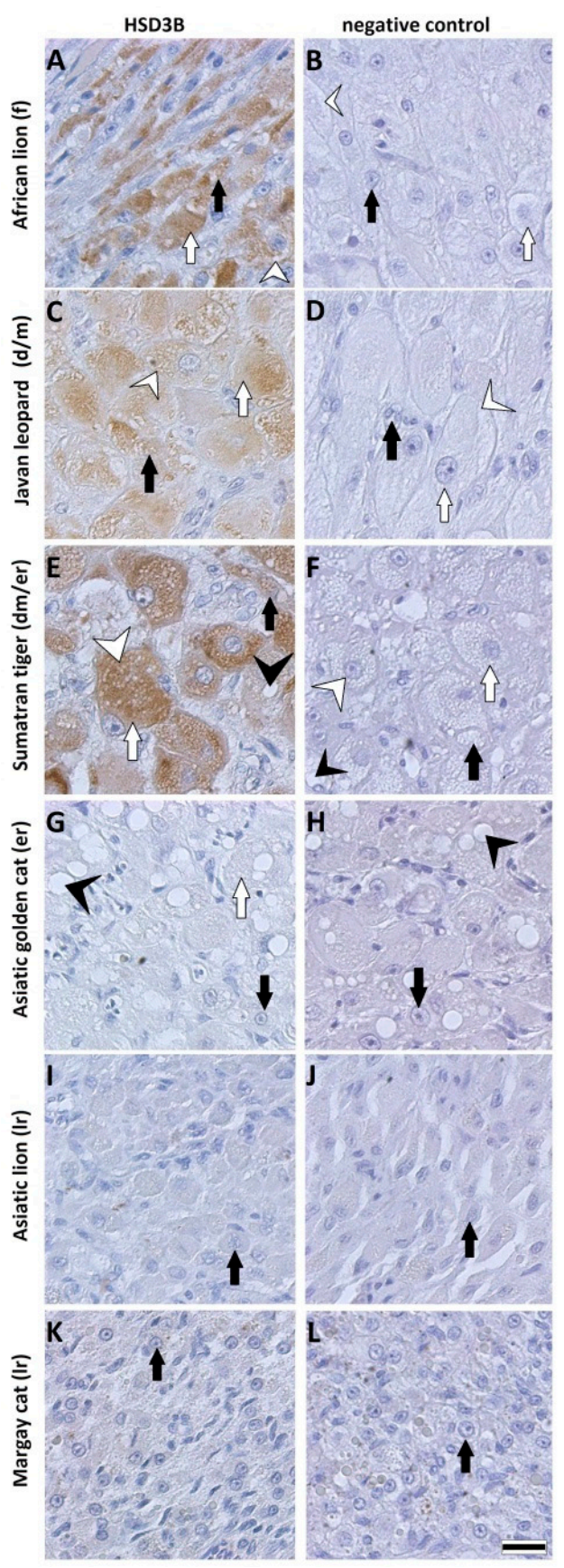

Figure 5. Immunohistochemical staining for HSD3B and negative control in CL from the African lion (A,B), Javan leopard (C,D), Sumatran tiger (E,F), Asiatic golden cat $(\mathbf{G}, \mathbf{H})$ Asiatic lion $(\mathbf{I}, \mathbf{J})$ and Margay cat $(\mathbf{K}, \mathbf{L})$. HSD3B protein signal was detected in a cytoplasm of SLC and LLC. $\mathrm{f}-$ formation, $\mathrm{dm}$-development/maintenance, er-early regression, lr-late regression. Scale bar is equal to $20 \mu \mathrm{m}$.

\section{Discussion}

To our knowledge, this is the first report of successful isolation and short-term culture of steroidogenic luteal cells from wild felids accompanied by functional testing for $\mathrm{LH}$ reception and HSD3B activity. Previously, steroidogenic luteal cells have been isolated and cultured in domestic cat $[20,25,26]$ and its functional testing was focused on cholesterol and cAMP [26].

The presented results confirmed that in described wild felids, the corpus luteum was composed of two types of steroidogenic cells, namely, small (SLC) and large luteal cells 
(LLC) (Figures 1 and 2), similarly to the domestic cat [20,25]. As expected, the composition of isolated steroidogenic luteal cells varied depending on species and CL stages (Table 3, Figure 2). We previously described that the enzymatic isolation method we used allowed us to obtain SLC from domestic cat CL almost exclusively (development/maintenance stage) because LLC were fragile and got lost by this method [20]. However, using the same isolation approach on CL from other felids, we obtained a mixture of isolated cells. Up to $16 \%$ of the populations were LLC, depending on the species and stage (Table 3). This may be due to species-specific differences towards enzymatic digestion and forces during isolation. The presented results also indicate that the number of isolated LLC was decreasing with the age of CL in wild felids (Table 3). Isolated cells from CL of wild felids during the formation stage were composed of more LLC, and the size of isolated cells steadily decreased with the age of CL. This is in agreement with our unpublished data in domestic cats, where we observed only in isolated cells from the formation stage (enzymatic method) a small number of large luteal cells, whereas they were nearly not present in isolations from later stages. Furthermore, cell size decreased during life cycle in the domestic cat. This is in contrast to results of Arikan et al., who used a different enzymatic method and were able to isolate more LLC from the cell populations of the domestic cat, with higher percentages of LLC in older CL [25]. As LLC of different CL stages could contain two types of vacuolization [8], we suggest that such vacuoles could be cellular structures that limit the isolation of LLC by our enzymatic method in felids.

We used P4 secreted to culture medium to describe the functionality of luteal cells. Previously, we observed a steep drop in hormone content after the first medium change in luteal cell culture [20], suggesting that the hormone decrease reflected the adaptation to culture condition during day 1 . The immediate decrease in steroid producing activity after inoculation to the culture disk has been described for rat and bovine luteal cells [27,28]. Regardless, we found tremendous differences in P4 concentration between the species and stages, although the inoculated luteal cell concentration was identical. Very high $\mathrm{P} 4$ secretion to cell culture medium was found for the earlier CL stages of wild felids (Figure $3 \mathrm{~A}, \mathrm{C}$ ), but for these cell cultures, the decrease in P4 concentration between day 1 and day 2 was greater than $80 \%$, although the total $\mathrm{P} 4$ concentration was still at least 10 times higher compared to cultures obtain from regression stages. Interestingly, we did not observe a decrease in P4 for luteal cells of the Asiatic golden cat (Figure 3D). This sample was also interesting because the CL expressed minor morphological signs of regression (Figure 1H), but HSD3B activity and IHC signals were already reduced, confirming functional regression preceding the structural regression [15]. Furthermore, as shown for the domestic cat, luteal cells of the regression stage (Figure 3E) produced around five times less $\mathrm{P} 4$ than those from the development/maintenance stage (Figure 3B), which somehow mirror the differences of intraluteal P4 during the CL lifespan [8]. Based on the data for domestic cat and our observation for the culture of luteal cells from wild felid species, we postulate that the very high discrepancies in P4 concentration between the luteal cell cultures from different species presented here were influenced by the different stages of CL. Our results for P4 (Figure 3) were reflected by the steroidogenic enzyme (HSD3B) protein expression (Figures 4 and 5), where this essential enzyme was only clearly detectable during the formation and development/maintenance stages of the CL lifespan. Another factor, which might have had a great impact on P4 secretion, is the composition of the cell cultures. The LLC are known to produce several times more P4 than SLC [20,29-31]. Therefore, it is consistent that cell culture from the African lion (CL formation), which has the highest number of LLC, had the highest P4 concentration in the medium (Figure 3A). In addition, mixed cell cultures may be better for both types of steroidogenic luteal cells, mimicking the in vivo conditions and allowing the interactions between both steroidogenic cell types. Previous studies on luteal cells from sheep and pigs showed that SLC and LLC cultured separately produce less progesterone that when they were cultured together $[32,33]$. The positive impact on in vitro P4 production was also influenced by non-steroidogenic cells in rats [27]. Here, we observed that in mixed 
cell cultures (wild felids, enzymatic isolation method), LLC behaved differently from LLC of domestic cat (mechanically separated and cultured separately) with regards to morphology [20]. Previously, we showed that LLC mostly do not attach to the bottom of a culture well [20], whereas here, we frequently observed the attachment of LLC (Figure 2). This might indicate better culture condition in cases of mixed cell cultures or an isolation of different LLC subtypes caused by the different isolation methods. It might be suggested that the time between ovariectomy and tissue preparation (transport to the lab) is a limiting factor; however, previous studies showed that storage of ovaries in cooled saline solution

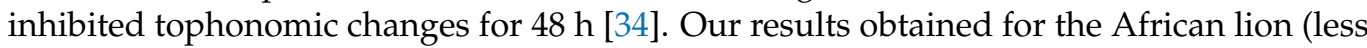
than $24 \mathrm{~h}$ transport) and the Javan leopard (less than $5 \mathrm{~h}$ transport) did not indicate a big difference. Possibly, the large differences in $\mathrm{P} 4$ concentrations could also be caused by individual [16] and/or species-specific characteristics. Thongphakdee et al. described that $\mathrm{P} 4$ peak concentration in fecal samples of pregnant females can vary up to five times between species [4], but this could be influenced by the number of CL or by different CL sizes too and may not be the result of different P4 expression capacity of luteal cells.

Experiments on different species which investigated the influence of LH on luteal cells used concentrations in a range between 10 and $100 \mathrm{ng} / \mathrm{mL}[28,35]$. For our experiments, using limited and rare materials, we decided to use a concentration of $100 \mathrm{ng} / \mathrm{mL}$, which was previously reported to cause significant changes on estradiol production in cultured granulosa cells from the domestic cat [36]. The used concentration also matched the serum LH peak (over $70 \mathrm{ng} / \mathrm{mL}$ ) during estrus of the domestic cat [17], but was higher than during the luteal phase of a pregnant queen, in which variable concentrations were measured [16]. Our preliminary experiments on the domestic cat showed that concentrations of $10 \mathrm{ng} / \mathrm{mL}$ and $100 \mathrm{ng} / \mathrm{mL}$ had almost the same stimulatory effect for P4 production (data not shown), but as we did not have the possibility to test it on samples from wild species, we decided to use $100 \mathrm{ng} / \mathrm{mL}$ LH in case cells from the wild felid species require a higher concentration of $\mathrm{LH}$.

We observed LH stimulatory effect for different approaches. Our experiments demonstrated that the almost pure population of SLC (domestic cat) was able to increase P4 production after LH treatment. However, the increase was not as pronounced as described for other species, where P4 concentration in LH treatment group increased several fold in comparison to control group [37]. The luteal cell of wild felids did react to LH (based on measured values, statistical analysis was not performed, $n=1$ ), but not in some cultures of cells that were in the regression stage. The stimulatory effect of LH on P4 production of cultured luteal cells was also investigated in other species, e.g., goat [35], pig [38-40], sheep [33] and cow [37,41]. Some of these experiments revealed that LH expressed an exclusive or higher stimulatory effect on SLC than on LLC, as a result of a higher number of LHR on small luteal cells. Previously published information about LHR receptor gene expression in SLC and LLC of domestic cat confirmed a different expression on a gene level [20]. At least for felids, we suggest that LLC also respond to LH stimulation.

The decreased activity in expression of HSD3B measured by IHC in the early regression stage of CL is most probably caused by an influence of a luteolytic hormone, of which the action led to functional regression of the gland and shutdown of progesterone production. This result is supported by mRNA analysis for HSD3B in pseudo-pregnant cats, where its expression significantly decreased between the development/maintenance and early regression stage [24].

\section{Conclusions}

In conclusion, our data indicate that the previously established enzymatic isolation method of small luteal cells in the domestic cat can be successfully applied to other felid species, but the ratio of isolated SLC to LLC may be different in comparison to the domestic cat. The results for immunohistochemistry staining revealed that signals of HSD3B decreases after the development/maintenance stage of the gland and indicates functional luteal regression. Obtained results from selected wild felid species were mostly matching 
to the results of the domestic cat, which is a model species for felids; however, the statistical analysis was not performed for them because of single samples from each species. LH was confirmed to cause a significant increase in P4 production in cultured luteal cells from the development/maintenance stage of domestic cat and caused an increase in P4 concentration in cultured luteal cells from CL of different wild felids at formation and development/maintenance. There was no effect of LH on P4 production in cultured luteal cells of the domestic cat and Asiatic lion CL during the regression stage and a minor stimulatory effect on cells from Asiatic golden cat CL during the early regression stage; therefore, we postulate that the influence of $\mathrm{LH}$, at least in the domestic cat, is dependent on the CL stage. Furthermore, we showed that it is worthwhile to conduct experiments on model species together with single experiments on samples occasionally obtained from rare species. With the limitations of samples from wild felids, this allows to study their functionality of the corpus luteum, or at least a part of it.

Author Contributions: Conceptualization, M.M.H., K.J. and B.C.B.; methodology, M.M.H., K.J. and B.C.B.; formal analysis, M.M.H.; investigation, M.M.H.; resources, M.M.H., K.J. and B.C.B.; data curation, M.M.H.; writing—original draft preparation, M.M.H.; writing—review and editing, M.M.H., K.J. and B.C.B.; visualization, M.M.H.; supervision, K.J. and B.C.B.; project administration, K.J. and B.C.B.; funding acquisition, K.J. and B.C.B. All authors have read and agreed to the published version of the manuscript.

Funding: This research was funded by the German Research Foundation; grant number DFG BR 4021/5-1. The publication of this article was funded by the Open Access Fund of the Leibniz Association.

Institutional Review Board Statement: This study was approved by the Internal Committee for Ethics and Animal Welfare of the Leibniz Institute for Zoo and Wildlife Research (IZW) (2017-02-02). The reason for the ovariectomies was not related to the purpose of this experiment.

Data Availability Statement: The data presented in this study are available on request from the corresponding author.

Acknowledgments: We greatly thank Sigrid Holz for making histological slides and staining, Kristina Knaub, Mareen Albrecht and Katrin Paschmionka for hormone extraction and measurements. We also would like to thank Celina Haße for performing immunohistochemical staining. We thank Givskud Zoo in Denmark, Tierpark Berlin, Allwetterzoo Münster, Aalborg Zoo in Denmark and Zoo Frankfurt for providing the samples. We thank Arjun Dheer and Shauna Kehoe for proofreading the manuscript for English language.

Conflicts of Interest: The authors declare no conflict of interest.

\section{References}

1. Brown, J.L. Female reproductive cycles of wild female felids. Anim. Reprod. Sci. 2011, 124, 155-162. [CrossRef] [PubMed]

2. Andrews, C.J.; Thomas, D.G.; Yapura, J.; Potter, M.A. Reproductive biology of the 38 extant felid species: A review. Mammal Rev. 2018, 49, 16-30. [CrossRef]

3. Brown, J.L. Comparative ovarian function and reproductive monitoring of endangered mammals. Theriogenology 2018, 109, 2-13. [CrossRef] [PubMed]

4. Thongphakdee, A.; Tipkantha, W.; Punkong, C.; Chatdarong, K. Monitoring and controlling ovarian activity in wild felids. Theriogenology 2018, 109, 14-21. [CrossRef]

5. Thongphakdee, A.; Sukparangsi, W.; Comizzoli, P.; Chatdarong, K. Reproductive biology and biotechnologies in wild felids. Theriogenology 2020, 150, 360-373. [CrossRef]

6. Schramm, R.D.; Briggs, M.B.; Reeves, J.J. Spontaneous and induced ovulation in the lion (Panthera leo). Zoo Biol. 1994, 13, 301-307. [CrossRef]

7. Niswender, G.D.; Juengel, J.L.; Silva, P.J.; Rollyson, M.K.; McIntush, E.W. Mechanisms Controlling the Function and Life Span of the Corpus Luteum. Physiol. Rev. 2000, 80, 1-29. [CrossRef]

8. Amelkina, O.; Braun, B.C.; Dehnhard, M.; Jewgenow, K. The corpus luteum of the domestic cat: Histologic classification and intraluteal hormone profile. Theriogenology 2015, 83, 711-720. [CrossRef]

9. Paape, S.R.; Shille, V.M.; Seto, H.; Stabenfeldt, G.H. Luteal Activity in the Pseudopregnant Cat. Biol. Reprod. 1975, 13, 470-474. [CrossRef] 
10. Tsutsui, T.; Stabenfeldt, G.H. Biology of ovarian cycles, pregnancy and pseudopregnancy in the domestic cat. J. Reprod. Fertil. Suppl. 1993, 47, 29-35.

11. Dawson, A.B. The postpartum history of the corpus luteum of the cat. Anat. Rec. Adv. Integr. Anat. Evol. Biol. 1946, 95, 29-51. [CrossRef] [PubMed]

12. Painer, J.; Jewgenow, K.; Dehnhard, M.; Arnemo, J.M.; Linnell, J.D.C.; Odden, J.; Hildebrandt, T.B.; Goeritz, F. Physiologically Persistent Corpora lutea in Eurasian Lynx (Lynx lynx)—Longitudinal Ultrasound and Endocrine Examinations Intra-Vitam. PLoS ONE 2014, 9, e90469. [CrossRef] [PubMed]

13. Swanson, W.F.; Roth, T.L.; Brown, J.L.; Wildt, D.E. Relationship of Circulating Steroid Hormones, Luteal Luteinizing Hormone Receptor and Progesterone Concentration, and Embryonic Mortality during Early Embryogenesis in the Domestic Cat. Biol. Reprod. 1995, 53, 1022-1029. [CrossRef] [PubMed]

14. Alila, H.W.; Hansel, W. Origin of Different Cell Types in the Bovine Corpus Luteum as Characterized by Specific Monoclonal Antibodies. Biol. Reprod. 1984, 31, 1015-1025. [CrossRef]

15. Meidan, R. The Life Cycle of the Corpus Luteum; Springer International Publishing: Cham, Switzerland, 2017.

16. Schmidt, P.M.; Chakraborty, P.K.; Wildt, D.E. Ovarian activity, circulating hormones and sexual behavior in the cat. II. Relationships during pregnancy, parturition, lactation and the postpartum estrus. Biol. Reprod. 1983, 28, 657-671. [CrossRef]

17. Wildt, D.E.; Chan, S.Y.; Seager, S.W.; Chakraborty, P.K. Ovarian Activity, Circulating Hormones, and Sexual Behavior in the Cat. I. Relationships during the Coitus-Induced Luteal Phase and the Estrous Period without Mating. Biol. Reprod. 1981, 25, 15-28. [CrossRef]

18. Banks, D.H.; Stabenfeldt, G. Luteinizing Hormone Release in the Cat in Response to Coitus on Consecutive Days of Estrus. Biol. Reprod. 1982, 26, 603-611. [CrossRef]

19. Painer, J.; Goeritz, F.; Dehnhard, M.; Hildebrandt, T.B.; Naidenko, S.V.; Sanchez, I.; Muñoz, M.A.Q.; Jewgenow, K. Hormoneinduced luteolysis on physiologically persisting corpora lutea in Eurasian and Iberian lynx (Lynx lynx and Lynx pardinus). Theriogenology 2014, 82, 557-562. [CrossRef]

20. Hryciuk, M.M.; Braun, B.C.; Bailey, L.D.; Jewgenow, K. Functional and Morphological Characterization of Small and Large Steroidogenic Luteal Cells From Domestic Cats Before and During Culture. Front. Endocrinol. 2019, 10, 724. [CrossRef]

21. Fernandez-Gonzalez, L.; Müller, K.; Jewgenow, K.; Zahmel, J. Felid-gamete-rescue within EAZA-Efforts and results in biobanking felid oocytes and sperm. J. Zoo Aquar. Res. 2019, 7, 1. [CrossRef]

22. Dehnhard, M.; Naidenko, S.; Frank, A.; Braun, B.; Göritz, F.; Jewgenow, K. Non-invasive Monitoring of Hormones: A Tool to Improve Reproduction in Captive Breeding of the Eurasian Lynx. Reprod. Domest. Anim. 2008, 43, 74-82. [CrossRef] [PubMed]

23. Braun, B.C.; Vargas, A.; Jewgenow, K. The molecular detection of relaxin and its receptor RXFP1 in reproductive tissue of Felis catus and Lynx pardinus during pregnancy. Reproduction 2012, 143, 399-410. [CrossRef] [PubMed]

24. Zschockelt, L.; Amelkina, O.; Siemieniuch, M.J.; Köster, S.; Jewgenow, K.; Braun, B.C. Corpora lutea of pregnant and pseudopregnant domestic cats reveal similar steroidogenic capacities during the luteal life span. J. Steroid Biochem. Mol. Biol. 2014, 144, 373-381. [CrossRef] [PubMed]

25. Arikan, Ş.; Yigit, A.; Kalender, H. Size Distribution of Luteal Cells during Pseudopregnancy in Domestic Cats. Reprod. Domest. Anim. 2009, 44, 842-845. [CrossRef] [PubMed]

26. Arikan, S.; Yigit, A.A. Effects of cholesterol and cAMP on progesterone production in cultured luteal cells isolated from pseudopregnant cat ovaries. Anim. Reprod. Sci. 2009, 115, 238-246. [CrossRef] [PubMed]

27. Nelson, S.E.; McLean, M.P.; Jayatilak, P.G.; Gibori, G. Isolation, characterization, and culture of cell subpopulations forming the pregnant rat corpus luteum. Endocrinology 1992, 130, 954-966. [CrossRef]

28. O'Shaughnessy, P.J.; Wathes, D.C. Characteristics of bovine luteal cells in culture: Morphology, proliferation and progesterone secretion in different media and effects of LH, dibutyryl cyclic AMP, antioxidants and insulin. J. Endocrinol. 1985, 104, 355-361. [CrossRef]

29. Fitz, T.A.; Mayan, M.H.; Sawyer, H.R.; Niswender, G.D. Characterization of Two Steroidogenic Cell Types in the Ovine Corpus Luteum. Biol. Reprod. 1982, 27, 703-711. [CrossRef]

30. Friden, B.E.; Hagström, H.-G.; Lindblom, B.; Sjoblom, P.; Wallin, A.; Brannstrom, M.; Hahlin, M. Cell characteristics and function of two enriched fraction of human luteal cells prolonged culture. Mol. Hum. Reprod. 1999, 5, 714-719. [CrossRef]

31. Lemon, M.; Loir, M. Steroid release in vitro by two luteal cell types in the corpus luteum of the pregnant sow. J. Endocrinol. 1977, 72, 351-359. [CrossRef]

32. Lemon, M.; Mauléon, P. Interaction between two luteal cell types from the corpus luteum of the sow in progesterone synthesis in vitro. Reproduction 1982, 64, 315-323. [CrossRef]

33. Harrison, L.M.; Kenny, N.; Niswender, G.D. Progesterone production, LH receptors, and oxytocin secretion by ovine luteal cell types on Days 6,10 and 15 of the oestrous cycle and Day 25 of pregnancy. Reproduction 1987, 79, 539-548. [CrossRef] [PubMed]

34. Wood, T.C.; Montali, R.J.; Wildt, D.E. Follicle-oocyte atresia and temporal taphonomy in cold-stored domestic cat ovaries. Mol. Reprod. Dev. 1997, 46, 190-200. [CrossRef]

35. Kalender, H.; Arikan, Ş.; Simsek, O. The effects of LH on progesterone production by cell subpopulations isolated from early and late luteal phase goat corpora lutea. Turk. J. Vet. Anim. Sci. 2014, 38, 433-438. [CrossRef]

36. Simsek, O.; Arikan, S. Effects of cholesterol, FSH and LH on steroidogenic activity of cat granulosa cells cultured in vitro. Anim. Reprod. 2015, 12, 931-938. 
37. Ursely, J.; Leymarie, P. Varying response to luteinizing hormone of two luteal cell types isolated from bovine corpus luteum. J. Endocrinol. 1979, 83, 303-310. [CrossRef]

38. Yuan, W.; Connor, M.L.; Buhr, M.M. Responsiveness of porcine large and small luteal cells to luteotropic or luteolytic hormones and cell morphologic changes during the estrous cycle and pregnancy. J. Anim. Sci. 1993, 71, 481-491. [CrossRef]

39. Hoffman, Y.M.; Peegel, H.; Sprock, M.J.E.; Zhang, Q.-Y.; Menon, K.M.J. Evidence that Human Chorionic Gonadotropin/Luteinizing Hormone Receptor Down-Regulation Involves Decreased Levels of Receptor Messenger Ribonucleic Acid*. Endocrinol. 1991, 128, 388-393. [CrossRef]

40. Zhang, L.; Huang, Y.; Wang, Z.; Luo, X.; Zhang, H.; Du, Q.; Chang, L.; Zhao, X.; Tong, D. Establishment and characterization of a telomerase immortalized porcine luteal cells. Theriogenology 2017, 94, 105-113. [CrossRef]

41. Nishimura, R.; Shibaya, M.; Skarzynski, D.J.; Okuda, K. Progesterone Stimulation by LH Involves the Phospholipase-C Pathway in Bovine Luteal Cells. J. Reprod. Dev. 2004, 50, 257-261. [CrossRef] 